\title{
A Gravity Model Analysis for Trade between Cameroon and Twenty-Eight European Union Countries
}

\author{
Eric Doumbe Doumbe1* ${ }^{*}$, Thierry Belinga ${ }^{2}$ \\ ${ }^{1}$ School of International Trade and Economics, University of International Business and Economics, Beijing, \\ China \\ ${ }^{2}$ School of Economics, Wuhan University of Technology, Wuhan, China \\ Email: "lildodoer@yahoo.fr, tbelinganet@yahoo.fr
}

Received 23 July 2015; accepted 17 August 2015; published 20 August 2015

Copyright (C) 2015 by authors and Scientific Research Publishing Inc.

This work is licensed under the Creative Commons Attribution International License (CC BY).

http://creativecommons.org/licenses/by/4.0/

(c) (1) Open Access

\begin{abstract}
The purpose of this empirical analysis is to investigate, based on gravity model, Cameroon's bilateral trade flows with Twenty-Eight European Union countries signatories of the EU-Cameroon Free Trade Agreement (FTA) on the $1^{\text {th }}$ of January 2009. Though the said Agreement entry into force day was scheduled for the $4^{\text {th }}$ of August 2014, it is important to analyze the trade trends among these 29 countries. The research findings reveal that Cameroon's bilateral trade with European Union countries is affected positively by economic size and per capita GDP, and influenced negatively by the distance between the trading partners. The result of basic the gravity model reveals that the Product of two countries' GDPs has positive and significant impact on bilateral trade, indeed, a 1 percent point increase in product of the GDPs leads to increase in the bilateral trade volume of Cameroon with the concerned trade partners by 1.2808 percent and about the distance factor, 1 percent point increase in distance leads to decrease the bilateral trade volume of Cameroon by 2.0306 percent.
\end{abstract}

\section{Keywords}

Gravity Model, Total Trade Volume, EU-Cameroon FTA

\section{Introduction}

With the vision 2035, Cameroon Government, like most of those of developing nations, has an objective to

${ }^{*}$ Corresponding author. 
achieve sustainable economic development and the poverty reduction. As International trade appears to be one of the means available to developing nations to reach such goals, they can attempt to reduce poverty by raising its share in the world's total exports. Therefore it is important to explore the major determinants of Cameroon's bilateral trade volume.

It is unavoidable to affirm that countries are more closely linked through trade. For the past 20 decades we have seen a tremendous change in international trade policies, new strategies like free trade, trade liberalization are more often mentioned in public's news.

To give an answer to the question why countries trade, [1] states that Adam Smith introduced the argument of absolute advantage, meaning that countries specialize in the production of goods according to their absolute advantage, then trade with others, they all gain in international trade. Though this thought cannot explain, the reason for country which does not have absolute advantage to get involve in international trade, [1] continues arguing that David Ricardo responded to that lack of answer by introducing the comparative advantage mentioning that "a nation, like a person, gains from trade by exporting the goods or services in which it has its greatest comparative advantage in productivity and importing those in which it has the least comparative advantage". In [2] we realize that even with the development of the Ricardian Model for International Trade, we were still remained with three main issues. His model assumes an extreme degree of specialization, which utopist. Secondly, it forecasts that all the nations gain from trading because it does not consider the impacts of international trade on income distribution within countries. Thirdly, his model does not include different resources among countries, the role of economies of scales and intra industry.

Reference [1] also argues that due to the classical theory limitations with regards to trade, Hecksher and Ohlin had extended the Ricardian model and developed an influential theory of trade known as factor endowment or Hecksler-Ohlin model. The model predicts that countries export products that use abundant factors intensively and import using scarce factors intensively.

As in [3] Krugman and other researchers introduced the new trade theory that analyzes the world trade based on the economics of scale, imperfect competition and product differentiation which relax the strict assumptions of classical theory of constant return to scale perfect competition and homogeneous goods. According to this theory of trade, [4] states trade occurs even when countries do not differ in their resources or technology.

Even having developed models on international trade, classical and new trade theory do not answer the question of size of the trade flows and that is where the gravity model comes in. For instance, [5] attempted to analyze the trade pattern of Georgia using gravity model approach. For this purpose, panel data set for time period 2000 to 2011 was used. Results of the study showed that size of the economies positively affect Georgia's trade volume. Also GDP per capita and common history was explored by the findings to be important determinants of trade pattern of Georgia. A positive correlation of foreign direct investment with trade was also confirmed by the findings of the study.

The main objective of the current study is to test the applicability of gravity model to bilateral trade flows in case of EU-Cameroon. Gravity analysis is intended to be used for deriving important implications regarding Cameroon's trade policy.

\section{Literature Review}

\subsection{Gravity Model for Trade: Definition and Evolution}

The classical and new trade theory can successfully explain the reasons for countries to enter the World Trade; but they cannot answer the question of the size of the trade flows. Another trade theory, the gravity model, which has been used intensively in analyzing patterns and performances of international trade in recent years, can be applied to quantify the trade flows empirically. The model applies Newton's universal law of gravitation in physics, which states that the gravitational attraction between two objects in proportional of their masses and inversely to square of their distance.

Reference [6] states that Tinbergen was the first to apply this gravity model to analyze international trade flows in 1962 and many others had followed to set up a series of econometric model of bilateral trade flows. The general gravity model applied in bilateral trade has the following form: $T_{i j}=A\left(Y_{i} Y_{j}\right) / D_{i j}$. Where $A$ is a constant term, $T_{i j}$ is the total trade flow from origin country I to destination country $j . Y_{i}, Y_{j}$ are the economic size of the two country I and $j$. $Y_{i}, Y_{j}$ are usually gross domestic product (GDP) or gross national product (GNP).

After the theoretical foundation of gravity model had been established, in the 1990s, further studies concen- 
trated on its empirical application. In Reference [7] we have a formulation of a more complex and advanced form of gravity equation where he particularly emphasized the role of geographical factors, such as distance, land lockedness and population, as determinants of bilateral trade flows. He also included regional trading blocs, such as APEC (Asia-Pacific Economic Cooperation), NAFTA (North American Free Trade Agreement), in his gravity equation in order to estimate the impact of regional integration on bilateral trade flows. In a similar way, [8] (1999) tries to analyze the impact of economic integration, as embodied by the LAIA (Latin American Integration Association), the Andean Pact, and CACM (Central American Common Market), in Latin American countries' Intra-regional trade flows, based on the gravity-type equation.

The research of [9] and [10], greatly contributed to the establishment of a theoretical foundation for the gravity model by showing that the gravity equation can be derived from a number of different international trade models.

\subsection{Limitations of the Model}

Reference [11] argues that one of the limitations of the gravity model is that it focuses on bilateral trade, and in fact only explains an increase or decrease in a bilateral trade flow. Still, the model is applied to issues of trade integration, where trade creations and diversions are key concepts. However, by assumption the model cannot explain substitutions between flows. Bikker in [12] extends the standard formulation of the gravity model in such a way that also substitutions between flows can be analyzed by constructing measurement of trade totals in the bilateral trade matrix.

In his research paper on gravity model analysis of Egypt's trade, El-Sayed in [13] emphasized that the intuitive gravity model is not free of difficulties once more advanced concepts from the trade literature are introduced. Considering the impact on trade between countries $i$ and $j$ of a change in trade costs between countries $i$ and $k$. An example of such a change might be that countries $i$ and $k$ enter into a preferential trade agreement that lowers tariffs on their respective goods. Basic economic theory suggests that such a move may well impact the trade of country $\mathrm{j}$, even though it is not party to the agreement. The well-known concepts of trade creation and trade diversion are examples of such effects. However, the intuitive gravity model does not account for this issue at all. Reducing trade costs on one bilateral route therefore does not affect trade on other routes in the basic model, which is at odds with standard economic theory. A second problem with the basic model arises if we consider equal decreases in trade costs across all routes, including domestic trade. An example could be a fall in the price of oil, which lowers transport costs everywhere, including within countries. In the basic model, this move would result in proportional increases in trade across all bilateral routes, including domestic trade. However, such an outcome sits ill with the observation that despite the change in trade costs, relative prices have not changed at all. In the absence of a change in relative prices, we would expect consumption patterns to remain constant for a given amount of total production (GDP). This is a second instance in which the basic gravity model makes predictions that are at odds with standard economic theory.

\subsection{EU-Cameroon Free Trade Agreement}

In the reference [14] it is stated that the European Union and the African, Caribbean and Pacific countries (ACP) have been working to put in place new Economic Partnership Agreements compatible with World Trade Organization (WTO) principles. These agreements have aim at progressively canceled barriers to trade and enhancing cooperation in all areas related to trade. They also aim at providing an open, transparent and predictable framework for free trade in goods and services, and enhance investment flows, thus increasing competitiveness of the ACP. Interim deals were initialed with a large number of countries or regions of the ACP at the end of 2007. The ACP countries decided themselves on the regional groupings for EPA negotiations. There are 6 such groups, four in Africa, one in the Pacific and the one in the Caribbean.

EU Development Commissioner Louis Michel in [14] said that Economic Partnership Agreements encourage developing countries to benefit from global trade, while maintaining a certain level of protection for some of their key interests. For him this agreement with Cameroon will pave the way for the regional integration sought after by Central African countries. It has a very strong development element that will support the implementation of reforms necessary for this regional integration.

With the above development the EU and Cameroon concluded negotiations on an interim Economic Partner- 
ship Agreement in 2007 [15]. According to [16], Cameroon and the EU authorities signed the Economic Partnership Agreement in 2009 and the Voluntary Partnership Agreement under the Forestry Law Enforcement, Governance and Trade process one year later. All sectors were included in the former deal except some sectors and especially nascent industries. The content was mainly focusing on agricultural and food processing products. The agreement was approved by the European Parliament in June 2013 and ratified by Cameroon in July 2014. This agreement provides duty-free, quota-free EU access for all goods from Cameroon and a gradual removal of duties and quotas over 15 years on $80 \%$ of EU exports to Cameroon. Besides trade in goods, the interim agreement also covers aid for trade, institutional issues, and dispute settlement. It also includes "rendezvous" clauses providing for further negotiations on other trade-related issues such as competition policy, intellectual property, etc. [15].

The Figure 1 show the general trend of Cameroon and European Union trade in goods. It shows a significant reduction of the trade balance after 2008.

\subsection{Ideas against the EU-Cameroon FTA}

According to [17] Pougala said that talking simply of free trade agreement between the EU and African countries like Cameroon is incorrect and speaking of competition between the French and Cameroonian farmer is incorrect since we are dealing here with free trade between a small African country, Cameroon, and mastodons of economics, industry and finance who have reduced European farmers to little slaves, transformed European politicians into beggarly puppets.

He continues saying that all European policies answer to the private interests of a few large financial and industrial groups in a very dangerous mixture of Thatcherism Liberalism and Reaganism. European politicians are only SRU (Sellers-Representatives-Ushers) of these oligarchies which, with assistance from the political system of universal suffrage, finance the election campaigns of the politicians, who then return the favor by passing laws to enslave their own citizens, reduced to a simple peons who must pay even for the air they breathe, in a machine which applies continuous pressure and prevents them from thinking or even revolting. The only alternative left for the citizen is suicide, as it is now the scourge of farmers across the European Union. In France, for example, every two days, one farmer commits suicide, driven to desperation by the oligarchs who control everything from fertilizer to supermarkets and even the toll highways. In any case it appears that the Thursday October $10^{\text {th }} 2013$ publication made by the Institute of Health Surveillance (INVS) as part of what the Institute

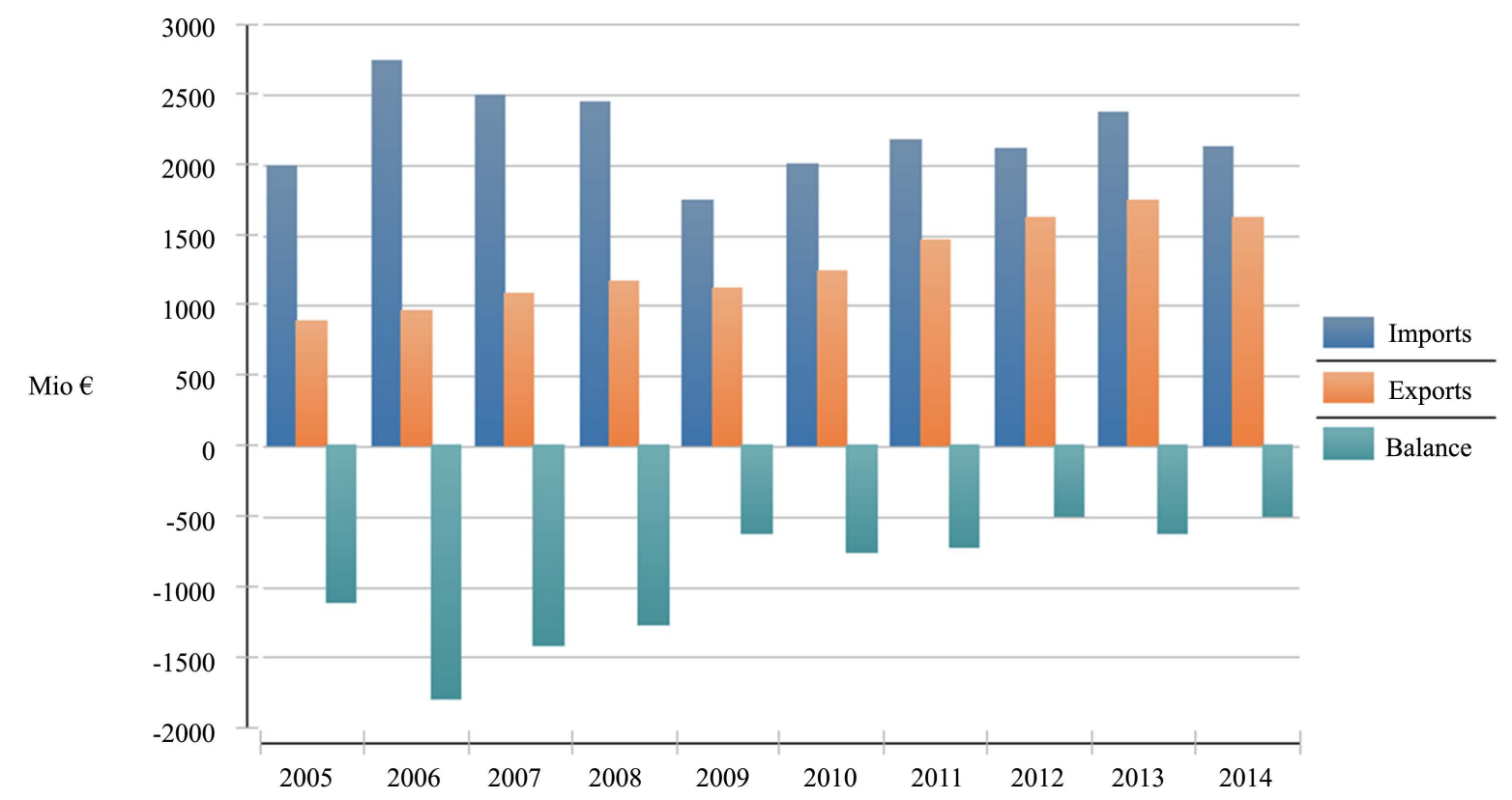

Figure 1. European Union trade with Cameroon (total goods: EU Trade flows and balance, annual data 2005-2014). Source: Eurostat Comext [21]. 
calls "The plan for suicide prevention in agriculture announced by the Ministry of Agriculture in March 2011". And according to this report, the first official study on this very taboo topic in Europe on the farmers' suicide, a farmer commits suicide every two days in France. Between 2007 and 2009, nearly five hundred farmer suicides that have been recorded. During this period, 417 men and 68 women who have committed suicide, because the fruit of their labor is not even allowed to repay the debts that the system was ha forced them to contract, supposedly, to improve their competitiveness by purchasing very expensive machines. While at the same time these same oligarchs (supermarkets) purchase at very low prices, fixed and imposed by the buyer, the milk or meat sold on shelves around the world.

Another example to illustrate the negative impact of the FTA can be seen prior to the signing of North American Free Trade Agreement (NAFTA) in 1994, when Canada was convinced it could profit from exporting cattle into the US, but now finds herself trapped by the unanticipated consequences. The debate in Canada at that time was naturally focused on the fact that US manufacturing would spill over into Canada. So, politicians in their calculations had concluded that the game was worth the gamble. But they had not anticipated that with this agreement, they simply would be swallowed by intrigues and predatory techniques of their American neighbor. They hadn't expected the perversions of any free trade agreement that in the end, it is the most ultraliberal party who wins. In a country where the population is small, only the construction of a strong State can preserve a better tomorrow, prosperity for all. But when engaging in an agreement which early-on announces its colors and portends to weaken the powers of the State and thence the purchasing power of its citizens, then we on track towards settling for a new and more insidious form of colonization whose name we dare not speak [17].

\section{Methodology}

\subsection{Estimation Method and Model}

Although panel data have certain advantages (e.g. panels can capture the relevant relationships among variables over time, and panels can monitor unobservable trading-partner-pairs individual effects), classical gravity model generally uses cross-section data to estimate trade effects and trade relationships for a particular time period, for example one year. Empirical literature of the gravity model using cross-section data is also huge. Further, [18] observes that aggregation over time does not really add any value to the estimations.

For estimation of the gravity model, we have followed [7] [18]-[20]. Since the dependent variable in the gravity model is bilateral trade (sum of exports and imports) between the pairs of countries, the product of GDP and the product of per capita GDP have been used as independent variables. We have added some additional independent variables in our model. The model is therefore "augmented" in the sense that several conditioning variables that may affect trade have been included. Thus the following gravity equation of trade for our regression analysis:

$$
\begin{aligned}
\log \left(\text { Trade }_{\mathrm{ij}}\right)= & \beta_{0}+\beta_{1} \log \left(\mathrm{GDP}_{\mathrm{i}} \cdot \mathrm{GDP}_{\mathrm{j}}\right)+\beta_{2} \log \left(\mathrm{PCGDP}_{\mathrm{i}} \cdot \mathrm{PCGDP}_{\mathrm{j}}\right) \\
& +\beta_{3} \log \left(\text { Distance }_{\mathrm{ij}}\right)+\beta_{4}(\text { Comlang_off })+\beta_{5}(\text { Colony })+\xi_{\mathrm{ij}}
\end{aligned}
$$

where

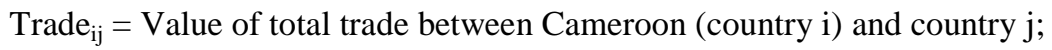

$\mathrm{GDP}_{\mathrm{i}}\left(\mathrm{GDP}_{\mathrm{j}}\right)=$ Gross Domestic Product of country i (j);

PCGDP $_{\mathrm{i}}\left(\right.$ PCGDP $\left._{\mathrm{j}}\right)=$ Per capita GDP of Country i $(\mathrm{j})$;

Distance $\mathrm{ij}_{\mathrm{ij}}=$ Distance between country $\mathrm{i}$ and country $\mathrm{j}$;

Comlang_off = Common official language (dummy variable);

Colony = Colonial relationship (dummy variable);

$\xi_{\mathrm{ij}}=$ is the regression error term.

As suggested by the economic theory, we expect positive signs for $\beta_{1}, \beta_{2}, \beta_{4}$ and $\beta_{5}$ and a negative sign for $\beta_{3}$.

Following are the hypotheses of this study:

- Trade volume of Cameroon with trade partners increases with increasing product of their economic sizes.

- Trade volume of Cameroon with its trade partner is significantly and negatively affected by the geographical distance between them.

- Common (official) languages between its trade partners positively affect trade volume. 
- Colony history between its trade partners has a positive and significant impact on the trade volume.

\subsection{Data and Sample Size}

The list of the Twenty-Eight European Union countries chose for this study is provided on Table 1.

The data are collected for the period of 2008 and 2012. All observations are annual. Data has been taken from Economic Outlook Database of IMF (2014). Annual data on trade (TR) is taken at constant 2000 US dollars. Annual data on Gross Domestic Product (GDP) and Per Capita (PC) is taken to measure the economic size of the economy based on Purchasing Power Parity. The distance variable (DST) represents the geographical distance between Cameroon's capital and its partner's capital. Bilateral distances and common (official) language come from the CEPII distance database (http://www.cepii.fr/anglaisgraph/bdd/distances.htm). An attempt to capture the impact of official language similarity has been done by this study. A dummy variable (comlang_off) is used for this purpose. Unity (1) is for the partners who have the same official language than Cameroon and zero (0) if not. Another dummy (colony) equal to unity for those countries that were ever in a colonial relationship with Cameroon has been used. There is evidence from the gravity model literature that each of these factors can sometimes exert a significant impact on trade flows, presumably because they increase or decrease the costs of moving goods internationally.

\section{Research Findings and Interpretation}

Table 2 exhibits OLS estimates, the Fixed Effects estimates and the Random Effects estimates of the gravity model from 2008 to 2012 data for our Equation (1):

The Hausman test for fixed versus random effects model shows a very high probability (0.9513), so we have to choose the Random Effects. Then, we perform the Breusch-Pagan LM test for random effects versus OLS. The P-value is very small (0.000), which means we shouldn't be using Pool OLS model, we should be using other individual specific effects. So, the explanation we to follow will consider the Random Effects estimates.

According to the results of Random Effects estimates for the gravity Equation (1), R-squared value is 0.7680 which indicates that the overall performance of the model is really good. The coefficient of determination $\left(\mathrm{R}^{2}\right)$ suggests that seventy six percent variations in the dependent variable are being explained by the explanatory variables. Significance of the model reveals that the bilateral trade flows of Cameroon is better explained by gravity model. Also, it is found to be well applicable to a single country case.

Estimation of gravity equation gave signs of coefficients as predicted by the economic theory. Result of basic gravity model revealed that Product of two countries' GDPs has positive and significant impact on bilateral trade. Its coefficient is 1.2808 and is significant at one percent level of significance. Its coefficient can be interpreted as keeping all other variables constant, a 1 percent point increase in product of the GDPs will on average lead to increase the bilateral trade volume of Cameroon with the concerned trade partners by 1.2808 percent. The product of the two countries' per capita GDPs also has positive and significant effect on bilateral trade at one percent level of significance. The value of its coefficient is estimated to be 1.7387 with a positive sign as was expected and can be interpreted as keeping all other variables constant, a 1 percent point increase in product

Table 1. 28 European Union countries signatories of the EU-Cameroon FTA on the 15 Jan 2009.

\begin{tabular}{|c|c|c|c|}
\hline \multicolumn{4}{|c|}{ Countries } \\
\hline Austria & Estonia & Italy & Portugal \\
\hline Belgium & Finland & Latvia & Romania \\
\hline Bulgaria & France & Lithuania & Slovak Republic \\
\hline Croatia & Germany & Luxembourg & Slovenia \\
\hline Cyprus & Greece & Malta & Spain \\
\hline Czech Republic & Hungary & Netherlands & Sweden \\
\hline Denmark & Ireland & Poland & United Kingdom \\
\hline
\end{tabular}


Table 2. Regression results base on the basic Gravity equation with three different estimations.

\begin{tabular}{|c|c|c|c|c|c|c|}
\hline \multirow[b]{2}{*}{ Explanatory variables } & \multicolumn{2}{|c|}{ Pool OLS } & \multicolumn{2}{|c|}{ Fixed Effects } & \multicolumn{2}{|c|}{ Random Effects } \\
\hline & Coef. & $P>|t|$ & Coef. & $P>|t|$ & Coef. & $\mathrm{P}>|\mathrm{z}|$ \\
\hline Constant & -3.5798 & 0.059 & -9.933 & 0.586 & -4.3004 & 1.137 \\
\hline $\log \left(G P_{i} \cdot G D P_{j}\right)$ & 1.3046 & 0.000 & 1.7959 & 0.44 & 1.2808 & 0.000 \\
\hline $\log \left(\right.$ PCGDPD $\left._{\mathrm{ij}}\right)$ & 1.6262 & 0.000 & 1.2442 & 0.717 & 1.7387 & 0.001 \\
\hline $\log \left(\right.$ Distance $\left._{\mathrm{ij}}\right)$ & -2.0127 & 0.000 & (dropped) & (dropped) & -2.0306 & 0.000 \\
\hline Comlang_off & 0.2288 & 0.110 & (dropped) & (dropped) & 0.1665 & 0.490 \\
\hline Colony & 0.1981 & 0.476 & (dropped) & (dropped) & 0.2692 & 0.585 \\
\hline $\mathrm{R}^{2}$ & \multicolumn{2}{|c|}{0.7685} & \multicolumn{2}{|c|}{0.6837} & \multicolumn{2}{|c|}{0.7680} \\
\hline $\mathbf{R}_{\text {adj }}^{2}$ & \multicolumn{2}{|c|}{0.7597} & & & & \\
\hline
\end{tabular}

Source: Author’s estimation.

of the per capita GDPs will on average lead to increase the bilateral trade volume of Cameroon with the concerned trade partners by 1.7387 percent. Distance variable is having negative sign with its coefficient value of 2.0306 and is found significant at one percent level of significance. Coefficient of the distance variable can be interpreted as keeping all other variables constant, a 1 percent point increase in distance will on average lead to decrease the bilateral trade volume of Cameroon by 2.0306 percent.

The dummies variables Comlang_off and Colony which are representing respectively the common official language and colonial relationship of any European Union country trading partner resulted to be non significant. They both have a positive coefficient respectively of 0.1665 and 0.2692 as predicted by the model. The simple meaning of the statistical insignificance implies that language and colonial relationship is not affecting Cameroon's and its trading partner bilateral trade volume. This is because of external interferences in formulation and setting of international trade relations. History shows that our trade policies and trade pattern are always dominated by third parties. These external interventions are made for achieving certain political goals. In addition, Cameroon's imports mainly comprise of technological items and it is well known that developed and large economies are the main exporters of technology.

In order to explore the unrealized trade potential of Cameroon with its trade partners, trade volumes which are estimated from gravity equation are compared with the actual trade volume for the year 2012.

Difference between predicted and actual trade volume for a specific trade partner for the year 2012 will represent the unrealized trade potential with it. Ratio of actual trade to predicted trade is taken for exploring the unrealized trade potential of Cameroon with its each European Union trade partner. These ratios are presented in Table 3.

A lower ratio country indicates a better partner for Free Trade Agreement (FTA). This will confirm that the elimination of trade barriers through FTA will lead to realization of the unexhausted trade potential, resulting in a larger expansion of trade by Cameroon. Countries with a ratio (in \%) lower than 100 haven't realized their full trade potential with Cameroon.

\section{Conclusion and Policies Recommendations}

Our results reveal that Cameroon's bilateral trade with the Twenty-Eight European Union countries is affected positively by economic size and per capita GDP, and negatively by the distance between the trading partners. The estimated results also show that, with the Twenty-Eight European Union countries signatories of the EUCameroon Free Trade Agreement, Cameroon hasn't realized its full trade potential with half of them namely Austria, Croatia, Czech Republic, Denmark, Estonia, France, Germany, Hungary, Italy, Poland, Romania, Slovak Republic, Sweden and United Kingdom.

Finally, as EU-Cameroon FTA effectively entered into force the $4^{\text {th }}$ of August 2014, time is needed to evaluate it again. As Cameroon is aiming to boost it economic growth thus the size of the whole economy, this FTA 
Table 3. Actual and predicted trade flows for the year 2012.

\begin{tabular}{|c|c|c|c|}
\hline Countries & Log actual trade flow (TR) & Log predicted trade flow (PTR) & TR/PTR (\%) \\
\hline Austria & 0.854593457 & 0.854593457 & 85.45934575 \\
\hline Belgium & 1.060753958 & 1.060753958 & 106.0753958 \\
\hline Bulgaria & 1.017143295 & 1.017143295 & 101.7143295 \\
\hline Croatia & 0.967810272 & 0.967810272 & 96.78102723 \\
\hline Cyprus & 1.040575735 & 1.040575735 & 104.0575735 \\
\hline Czech Republic & 0.916210121 & 0.916210121 & 91.62101214 \\
\hline Denmark & 0.943713413 & 0.943713413 & 94.37134133 \\
\hline Estonia & 0.972286651 & 0.972286651 & 97.22866514 \\
\hline Finland & 1.026816116 & 1.026816116 & 102.6816116 \\
\hline France & 0.970345701 & 0.970345701 & 97.03457007 \\
\hline Germany & 0.866943931 & 0.866943931 & 86.69439307 \\
\hline Greece & 1.036425953 & 1.036425953 & 103.6425953 \\
\hline Hungary & 0.951414266 & 0.951414266 & 95.14142664 \\
\hline Ireland & 1.030929763 & 1.030929763 & 103.0929763 \\
\hline Italy & 0.947696114 & 0.947696114 & 94.76961135 \\
\hline Latvia & 1.164781692 & 1.164781692 & 116.4781692 \\
\hline Lithuania & 0.994438 & 0.994438 & 99.443799997 \\
\hline Luxembourg & 1.000135143 & 1.000135143 & 100.0135143 \\
\hline Malta & 1.196343421 & 1.196343421 & 119.6343421 \\
\hline Netherlands & 1.042269704 & 1.042269704 & 104.2269704 \\
\hline Poland & 0.904435142 & 0.904435142 & 90.44351417 \\
\hline Portugal & 1.183858646 & 1.183858646 & 118.3858646 \\
\hline Romania & 0.986192868 & 0.986192868 & 98.61928682 \\
\hline Slovak Republic & 0.938234539 & 0.938234539 & 93.82345393 \\
\hline Slovenia & 1.120196248 & 1.120196248 & 112.0196248 \\
\hline Spain & 0.995980351 & 0.995980351 & 99.5980351 \\
\hline Sweden & 0.920595297 & 0.920595297 & 92.05952972 \\
\hline United Kingdom & 0.909955803 & 0.909955803 & 90.99558033 \\
\hline
\end{tabular}

Source: Author’s estimation.

might be advantageous for it economy. Further research is needed to assess the required production specialization in this exchange.

\section{References}

[1] Lindert, P.H. (1991) International Economics. 9th Edition, Homewood, Irwin.

[2] Thai Tri Do (2006) A Gravity Model of Trade between Vietnam and 23 European Countries. Department of Economics and Society, Dalarna University, Sweden.

[3] Krugman, P.R. and Maurice O. (2005) International Economics: Theory and Policy. 7th Edition, Addison-Wesley, 
Boston.

[4] Markusen, R.J., Melvin, R.J., Kaempfer, W. and Maskus, E.K. (1995) International Trade Theory and Evidence. McGrawHill, Boston.

[5] Dilanchiev, A. (2012) Empirical Analysis of Georgian Trade Pattern: Gravity Model. Journal of Social Sciences, 1, 75-78.

[6] Tinbergen, J. (1962) Shaping the World Economy: Suggestions for an International Economic Policy. The Twentieth Century Fund, New York.

[7] Frankel, J.A., Romer, D. and Cyrus, T. (1997) Regional Trading Blocs in the World Economic System. Institute for International Economics, Washington DC.

[8] Garman, G. and Debora, G. (1999) Economic Integration in the Americas: 1975-1992. Journal of Applied Business Research, 14, 1-12.

[9] Helpman, E.A.P.K. (1985) Market Structure and Foreign Trade: Increasing Returns, Imperfect Competition and the International Economy. MIT Press, Cambridge, MA.

[10] Bergstrand. J.H. (1989) The Generalized Gravity Equation, Monopolistic Competition, and the Factor-Proportions Theory in International Trade.

[11] Bergeijk and Brakman (2010) The Gravity Model of International Trade: Advances and Applications. Cambridge University Press, Business \& Economics.

[12] Bikker, J.A. (2009) An Extended Gravity Model with Substitution Applied to International Trade. DNB Working Paper No. 215, July 2009.

[13] Elshehawy, M., Shen, H. and Ahmed, R. (2014) The Factors Affecting Egypt's Exports: Evidence from the Gravity Model Analysis. Open Journal of Social Sciences, 2, 138-148. http://dx.doi.org/10.4236/jss.2014.211020

[14] (2009) European Union Commission Press Release Database. Brussels. http://europa.eu/rapid/press-release_IP-09-55_en.htm

[15] European Union Commission Trade. http://ec.europa.eu/trade/policy/countries-and-regions/regions/central-africa/

[16] European External Action Service. http://www.eeas.europa.eu/cameroon/index_en.htm

[17] Pougala, J.-P. (2013) Cameroon-EPA: Why Cameroon Should Not Sign the Final Ape Agreement. http://pougala.org/why-cameroon-should-not-sign-the-final-ape-agreement/

[18] Batra, A. (2006) India’s Global Trade Potential: The Gravity Model Approach. Global Economic Review, 35, $327-361$. http://dx.doi.org/10.1080/12265080600888090

[19] Rahman, M.M. (2003) A Panel Data Analysis of Bangladesh’s Trade: The Gravity Model Approach. Proceedings of the 5th European Trade Study Group Conference, Madrid, 11-13 September 2003, 1-54.

[20] Sharma, S.C. and Chua, S.Y. (2000) ASEAN: Economic Integration and Intra-Regional Trade. Applied Economics Letters, 7, 165-169. http://dx.doi.org/10.1080/135048500351726

[21] Eurostat Comext, Directorate-General for Trade of the European Commission. http://trade.ec.europa.eu/doclib/docs/2006/september/tradoc_122457.pdf 